\title{
Differences of Accumulated Heavy Metal Levels in End-Stage Liver Disease, Wilson's Disease, and Other Etiologies
}

\section{Karaciğerde Birikmiș Ağır Metal Düzeylerinin Kriptojenik Etiyoloji ile Wilson Hastalığı ve Diğer Etiyolojileri Açısından Farklılığı}

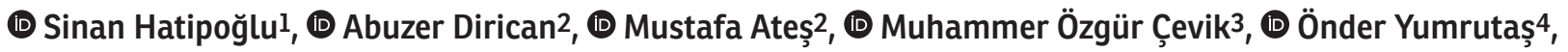 \\ (1) Muhammet Ali Ișık1, (1) Sezai Yılmaz²
}

IAdıyaman University Faculty of Medicine, Department of General Surgery, Adıyaman, Turkey

2ंnönü University Faculty of Medicine, Department of General Surgery, Malatya, Turkey

${ }^{3}$ Adıyaman University Faculty of Medicine, Department of Medical Genetics, Adıyaman, Turkey

${ }^{4}$ Adıyaman University Faculty of Medicine, Department of Medical Biology, Adıyaman, Turkey

\begin{abstract}
Objective: End-stage liver disease (ESLD) is a devastating condition, which leads to liver transplantation (LT). There are various proposed predisposing factors for ESLD. A significant proportion of ESLDs is of undetectable (cryptogenic) origin. Accumulation of heavy metals is a proposed but not thoroughly researched predisposing factor for ESLD. In this study, we measured the concentration of accumulated heavy metals in the explanted liver tissue of ESLD patients. Apart from various accompanying etiologies, such as rare hereditary diseases, infections, and tumors were also evaluated.

Method: This prospective study aimed to evaluate the concentrations of heavy metals in the explanted liver of consecutive patients with ESLD and different etiologies who underwent elective and/or emergency LT. Bioaccumulation of nine heavy metals ( $\mathrm{Hg}, \mathrm{As}, \mathrm{Zn}, \mathrm{Cr}, \mathrm{Pb}, \mathrm{Cu}, \mathrm{Ni}, \mathrm{Mg}$, and Fe) was evaluated by atomic absorption spectrophotometer in the explanted liver tissue of ESLD patients. Also, histopathologies of explanted livers and etiologies of patients were evaluated using data from histopathological techniques, medical records, or genetic counseling processes.

Results: The male/female ratio was 33:15. The results of our study showed no statistical significance in terms of total heavy metal levels in the explanted livers ( $p>0.05$ ), including patients with cryptogenic etiology. However, four patients with Wilson's disease had copper levels of 250 uq/g dried liver tissue. Histopathological examinations of explanted livers revealed that four (8\%) patients had Wilson's disease, one (2\%) patient had tyrosinemia, 15 (31\%) patients had unknown/undetectable (cryptogenic) etiology, 24 patients had viral infections (20 had hepatitis B virus infection, one had hepatitis C virus infection, three had multiple viral infections at once), one patient had a metastatic tumor, one patient had an unidentified autoimmune disease, and one patient had polycystic liver disease.

Conclusion: Accumulated total heavy metal levels in explanted livers of ESLD patients do not appear to be a differential diagnosis tool, except the copper levels for Wilson's disease. More research is needed to further elucidate the different roles of heavy metal concentrations in both normal and disease states of heavy metals in the liver.
\end{abstract}

Keywords: Unexplained hepatic failure, heavy metals, Wilson's disease, liver transplantation, atomic absorption spectrophotometer

Cite as: Hatipoğlu S, Dirican A, Ateș M, Çevik MÖ, Yumrutaș Ö, Işık MA, Yılmaz S. Differences of Accumulated Heavy Metal Levels in End-Stage Liver Disease, Wilson's Disease, and Other Etiologies. IKSSTD 2021;13(3):184-93 
ÖZ

Amaç: Son evre karaciğer hastalığı (SEKH), karaciğer nakline (KN) yol açan yıkıcı bir klinik durumdur. SEKH'nin etiyolojisinde çeșitli hazıılayııı faktörler mevcut olup hastaların önemli bir kısmında ise etiyoloji net olarak saptanamamaktadır (kriptojenik). Ağır metallerin karaciğerde birikmesi, SEKH'ye yol açan ancak kapsamlı bir șekilde araştııılmamış bir yatkınlık faktörüdür. Bu çalıșmada; nadir görülen kalıtsal hastalıklar, enfeksiyonlar, tümörler ve kriptojenik gibi eşlik eden çeşitli etiyolojiler nedeniyle gelişen SEKH olgularının karaciğer dokusunda biriken ağır metal konsantrasyonları değerlendirildi.

Yöntem: Bu prospektif çalışmada, elektif ve/veya acil KN uygulanan farklı etiyolojilere sahip SEKH mevcut olan hastaların rezeke edilmiş karaciğerindeki ağır metal konsantrasyonları değerlendirilmektedir. Dokuz adet ağır metalin ( $\mathrm{Hg}, \mathrm{As}, \mathrm{Zn}, \mathrm{Cr}, \mathrm{Pb}, \mathrm{Cu}, \mathrm{Ni}, \mathrm{Mg}$, Fe) birikim değerleri atomik absorpsiyon spektrofotometresi ile değerlendirildi. Rezeke edilen karaciğerlerin histopatolojileri ve etiyolojileri, tıbbi kayitlar ve/veya genetik danışma süreçlerinden elde edilen veriler kullanılarak değerlendirildi.

Bulgular: Erkek/kadın oranı 33/15 idi. Çalıșmamızın sonuçları değerlendirildiğinde; kriptojenik etiyolojisi olan hastalar da dahil olmak üzere rezeke edilen karaciğerlerdeki toplam ağır metal seviyeleri açısından istatistiksel anlamlılık görülmedi $(p>0,05)$. Bununla birlikte, Wilson hastalığı olan dört hastanın kurutulmuş karaciğer dokusunda bakır seviyeleri 250 uq/g üstündeydi. Rezeke karaciğerlerin histopatolojik incelemelerinde; dört hastada (\%8) Wilson hastalığ, bir hastada tirozinemi (\%2), on beș hastada kriptojenik etiyolojiye (\%31), yirmidört hastada viral enfeksiyon (20'sinde hepatit B virüs enfeksiyonu, birinde hepatit C virüsü enfeksiyonu, 3'ünde aynı anda birden fazla viral enfeksiyon), l'inde metastatik tümör, birinde tanımlanamayan otoimmün hastalık ve bir hastada ise polikistik karaciğer hastalığı vardı.

Sonuç: SEKH olgularının karaciğerlerinde biriken toplam ağır metal seviyeleri, Wilson hastalığı için bakır seviyeleri dışında ayırııı bir tanı aracı olarak görünmemektedir. Karaciğerdeki ağır metallerin hem standart hem de hastalık durumlarında ağır metal konsantrasyonlarının farklı rollerini açıklğa kavușturmak için daha fazla deneysel araştırmaya intiyaç vardır.

Anahtar kelimeler: Kriptojenik karaciğer yetmezliği, ağır metaller, Wilson hastalı̆̆ı, karaciğer nakli, atomik absorpsiyon spektrofotometresi

\section{INTORDUCTION}

End-stage liver disease (ESLD) is a devastating health problem. Although the etiology of ESLD depends on infectious, metabolic, toxic, and parasitic factors, the coexistence of more than one factor enhances liver damage (1). These damaged cells cause functional impairment of the liver and alter the metabolism of trace elements ${ }^{(2)}$. Current therapeutic options are limited, and liver transplantation (LT) is the best option in patients with ESLDs. However, donor scarcity is a global problem; therefore, preventing ESLD formation, if possible, especially in cryptogenic cases, should be one of the primary goals of LT research.

Accumulations of heavy metals have long been claimed to culminate in hepatic toxicity and are involved in chronic liver diseases ${ }^{(3)}$. Moreover, it is known that massive metal excretion into the biosphere has reached excessive levels ${ }^{(4)}$. Heavy metals are compounds found naturally in the Earth's crust, making them dangerous for human health if exposed in excess. Various research has proven the adverse effects of heavy metals on various organs and functions ${ }^{(5-7)}$. However, in literature, only a few studies have focused on the liver effects, especially acute toxicity and carcinogenicity, of excess heavy metal bioaccumulation ${ }^{(8-12)}$.

In this prospective study, we investigated the bioaccumulation of heavy metals in explanted liver tissue of ESLD patients using atomic absorption spectrometry (AAS) technique to find a correlation between heavy metal accumulation in failed livers explanted from ESLD patients and etiology (especially the unknown/cryptogenic).

\section{METHOD}

The pre-surgical medical history and post-surgery outcomes of patients with ESLD who underwent elective and/or emergency LT were evaluated. The study protocol was approved by the Adıyaman University Clinical Trials Ethics Committee for Medical Research and Institutional Review Board of the Medical Faculty of Adıyaman University (reference no: TIPFBAP/2014-0007).

Total hepatectomy specimens (explants) of patients who underwent consecutive LTs at Turgut Ozal Medical Center LT Unit of İnönü University, Malatya, Turkey, were evaluated by histological and atomic absorptiometry techniques. The damage of livers of all the recipient patients was proven by histological, radiological, and laboratory examinations. The patients with unknown etiology were named "cryptogenic ESLD" after there was no detectable biochemical, histological, serological, or hereditary cause detected. Clinical, histological, and laboratory data were evaluated for all participants. Causes of end-stage liver failure, demographics of recipient patients, laboratory tests, surgical details of the recipient procedures, histopathological findings, and 
levels of bioaccumulation of heavy metals in the livers were recorded. All patients who underwent consecutive LT due to ESLD were included in this study, while patients with a predetermined heavy metal poisoning clinic and history were excluded. Liver tissues of patients diagnosed with or without any cause (cryptogenic) ESLD and who underwent LT were included without any age or gender restriction.

The donor and recipient operations were initiated simultaneously and an intraparenchymal cubic core liver biopsy $\left(0.5 \mathrm{~cm}^{3}\right)$ is done from specimens of the total recipient hepatectomy (Figure 1). The recipient's total hepatectomy specimen was routinely sent to the pathology laboratory for biological examination and evaluation after the biopsy. Samples taken from pathological liver specimens were placed in sterile storage containers and stored at $-80{ }^{\circ} \mathrm{C}$ in freezer until use. Before analysis, samples were allowed to thaw overnight. The dissolved samples were washed with ultrapure water until all the blood on it was removed. After removing excess water from the samples with blotting paper, samples were weighed and a standard amount of tissue was taken from each sample and placed in $10 \mathrm{~mL}$ propylene tubes to form a weight standard. After adding an equal amounts (1: $\mathrm{l} \mathrm{v} / \mathrm{v}$ ) of $65 \% \mathrm{HNO}_{3}$ (Merck) and $35 \% \mathrm{HCl}$ (Merck) to these 10 $\mathrm{mL}$ propylene tubes, the tubes were kept in a water bath at 90 ${ }^{\circ} \mathrm{C}$ for 2 hours. Thus, all tissue in the tubes was homogenized. After the samples were homogenized, the levels of heavy metals were examined with the AAS device (Perkin Elmer AAnalyst 800) at the Scientific and Technological Research Center of Adıyaman University. Level of heavy metals were measured using the Graphite Furnace technique. Argon (200 $\mathrm{mL} / \mathrm{min}$ ) gas was used in the combustion medium in the Graphite Furnace AAS device.

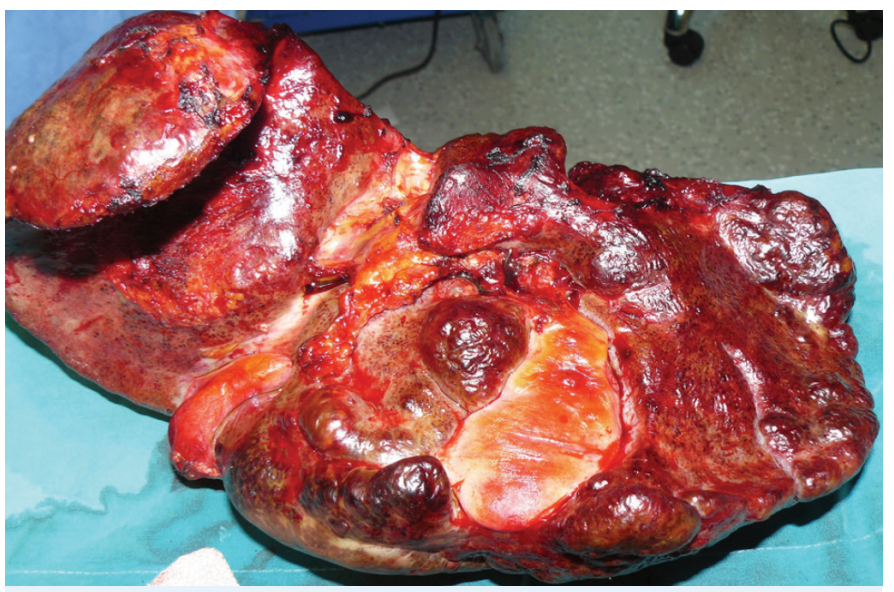

Figure 1. An intraparenchymal biopsy performed after the surgery from the explanted liver

\section{Statistical Analysis}

Data analysis and presentation of tables was done using SPSS Statistics for Windows, version 15.0 (SPSS Inc., Chicago, IIL., USA). Fisher's exact test, Kruskal-Wallis test, MannWhitney $U$ test, and unpaired t-test were applied where appropriate. Continuous variables were presented as means \pm standard deviations and categorical variables as numbers and percentages. $P$ values less than 0.05 were considered statistically significant.

\section{RESULTS}

The study group included 48 patients (females: $n=15, \%=$ 31.3; males $n=33, \%=68.7$ ) who underwent elective and/or emergency LT due to ESLD. Etiologies of the ESLD patients were infection due to hepatitis $B$ viruses (four patients were co-infected with HCC viruses) ( $n=20, \%=41.7$ ), Wilson's disease ( $n=4, \%=8.3)$, tyrozinemia $(n=1, \%=2.1)$, biliary atresia $(n=1, \%=2.1)$, cholangiocellular carcinoma $(n=1, \%$ $=2.1$ ), hepatitis $B$ and $C$ viruses co-infection ( $n=1, \%=2.1)$, hepatitis $B+C+D$ viruses triple infection ( $n=1, \%=2.1$ ), hepatitis $B+D$ viruses co-infection ( $n=1, \%=2.1$ ), hepatitis $C$ virus infection ( $n=1, \%=2.1$ ), metastatic adenocarcinoma $(n=1, \%=2.1)$, polycystic liver disease $(n=1, \%=2.1)$, autoimmune etiology $(n=1, \%=2.1$ ), and cryptogenic (unknown) etiology ( $n=15, \%=31.3$ ), (Table 1 ).

The histopathological evaluation revealed that cirrhosis - chronic liver disease $(n=37, \%=77.1)$, hepatocellular carcinoma (HCC) $(n=5, \%=10.4)$, fulminant hepatitis ( $n=$ $4, \%=8.3)$, cholangiocellular carcinoma $(n=1, \%=2.1)$, and

\section{Table 1. The etiologies of end-stage liver diseases}

\begin{tabular}{|l|l|}
\hline Histopathology of the explanted livers & Number (\%) \\
\hline Hepatitis B viruses & $20(41.7 \%)$ \\
\hline Cryptogenic (unknown etiology) & $15(31.3 \%)$ \\
\hline Wilson disease & $4(8.3 \%)$ \\
\hline Tyrozinemia & $1(2.1 \%)$ \\
\hline Biliary atresia & $1(2.1 \%)$ \\
\hline Autoimmune etiology & $1(2.1 \%)$ \\
\hline Cholangiocellular carcinoma & $1(2.1 \%)$ \\
\hline Metastatic adeno carcinoma & $1(2.1 \%)$ \\
\hline Polycystic liver disease & $1(2.1 \%)$ \\
\hline Hepatitis C viruses & $1(2.1 \%)$ \\
\hline Hepatitis B + hepatitis C viruses & $1(2.1 \%)$ \\
\hline Hepatitis B + hepatitis D viruses & $1(2.1 \%)$ \\
\hline $\begin{array}{l}\text { Hepatitis B + hepatitis C + hepatitis D } \\
\text { viruses }\end{array}$ & $1(2.1 \%)$ \\
\hline
\end{tabular}


metastatic adenocarcinoma ( $n=1, \%=2.1$ ) existed (Table 2 , 3). Clinical and pathological data of the explanted liver are summarized in Table 1-3.

The patients were classified under three groups for statistical analysis: HBV (group 1) vs. Cryptogenic (group 2) vs. Others (group 3), as seen in Table 3 and Figure 2. Statistical analysis revealed that there was no difference between the groups in terms of total heavy metal levels of $\mathrm{Hg}, \mathrm{As}, \mathrm{Zn}, \mathrm{Cr}, \mathrm{Pb}, \mathrm{Cu}, \mathrm{Ni}$, $\mathrm{Mg}$, and $\mathrm{Fe}(\mathrm{p}>0.05)$ and results did not differ in between genders $(p=0.311)$ as reflected in Figure 2 .

\section{DISCUSSION}

Heavy metal are metal elements with a density above $5 \mathrm{~g} / \mathrm{cm}^{3}$. More than 60 different elements, including lead, cadmium, chrome, iron, cobalt, copper, nickel, mercury, arsenic, and zinc, are classified as heavy metals ${ }^{(13)}$. Although heavy metals are natural constituents of both the Earth's crust and human body, fluctuations in their natural concentrations, due to various human activities, have resulted in their toxic bioaccumulation in tissues ${ }^{(14)}$. These activities include mining, smelting, welding, and other industrial applications or overuse of products, such as pesticides, fungicides, cosmetics, fuel, and particular medication (15-17).

The definition of the heavy metal in medical literature is broader than the physical one mentioned above and it applies to all metals that are toxic to the human body at specific concentrations, regardless of their atomic weight (14). The toxicity of heavy metals mainly stems from their interference with the body metalloenzymes, which are essential enzymes that are bound to metal cofactors ${ }^{(18)}$. The metalloenzymes perform many metabolic functions in the liver, such as enzymatic functions, oxidative damage, protein synthesis, antioxidant defense, interferon therapy response, and immunological competence (19). However, long-term exposure to uncommonly high levels of heavy metals has been shown to cause adverse health effects, such

Table 2. Histopathological characteristic data of the explanted livers of recipients

\begin{tabular}{|l|l|}
\hline Histopathology of the explanted livers & Number (\%) \\
\hline Chronic liver disease - cirrhosis & $37(77.1 \%)$ \\
\hline $\begin{array}{l}\text { Hepatocellular carcinoma - chronic liver } \\
\text { disease }\end{array}$ & $5(10.4 \%)$ \\
\hline Acute fulminant hepatitis & $4(8.3 \%)$ \\
\hline $\begin{array}{l}\text { Cholangiocellular carcinoma - chronic liver } \\
\text { disease }\end{array}$ & $1(2.1 \%)$ \\
\hline $\begin{array}{l}\text { Metastatic adeno-carcinoma - chronic liver } \\
\text { disease }\end{array}$ & $1(2.1 \%)$ \\
\hline
\end{tabular}

as cancer $(3,20,21)$. The liver is supposedly an indicator and target organ for the bioaccumulation of heavy metals ${ }^{(15)}$. Following oral exposure, heavy metals are usually absorbed by the gastrointestinal tract and are transported via the bloodstream to the liver where metabolism and conjugation occurs before excretion by the kidneys ${ }^{(22,23)}$. Therefore, the liver is the primary target of toxicity, given its role in the detoxification process ${ }^{(24)}$.

ESLD, a life-threatening clinical syndrome of acute or chronic liver dysfunction, is associated with coagulation abnormalities and encephalopathies in patients with or without preexisting cirrhosis ${ }^{(25)}$. Chronic ESLD can result in myofibroblast activation, dysregulated fibrosis, and cirrhosis, while continuous cell turnover can lead to the development of HCC $(22,23,26)$. Liver cirrhosis is the typical outcome of chronic liver injury. Cirrhosis and its complications, ascites, hepatic encephalopathy, variceal hemorrhage, infections and not, at least, $\mathrm{HCC}$ represent the end in the spectrum of chronic liver diseases, irrespective of the etiology ${ }^{(25-29)}$. LT is potentially the only curative modality, which has markedly improved the prognosis of patients with ESLD ${ }^{(25-29)}$.

Cryptogenic cirrhosis is commonly observed in LT patients. Differential diagnosis is made by excluding other causes of cirrhosis, such as viral, metabolic, alcoholic, autoimmune, toxic, and other minor reasons (30,31). Diagnosis of cryptogenic cirrhosis demands the completion of tests for viral hepatitis (hepatitis A, B, and C), auto-antibodies for autoimmune hepatitis (anti-smooth muscle antibody, antinuclear antibody, and antimitochondrial antibody), iron and ceruloplasmin levels, $\alpha-1$ antitrypsin phenotype, and histopathological analysis of liver biopsy. Besides, overt or unapparent alcoholism and hepatotoxic drug intake should also be excluded ${ }^{(30-33)}$.

Even with today's diagnostic technology, etiology may remain idiopathic in $5 \%$ to $30 \%$ of all liver cirrhosis cases and only $5 \%$ to $7 \%$ of these patients have access to LT (31). Correct diagnosis of patients with cryptogenic liver cirrhosis is critical for post-transplantation management and immunosuppressive planning. Various studies have confirmed that a detailed diagnostic workup before or after transplantation documents the definitive diagnosis in those patients with cryptogenic liver cirrhosis ${ }^{(30)}$. The term cryptogenic cirrhosis implies that no underlying etiology of the liver disease can be found, which is referred to as a diagnosis of exclusion.

In recent years, non-alcoholic steatohepatitis is becoming the most important cause of cirrhosis and hepatocellular carcinoma. Iron overload has been implicated in the 

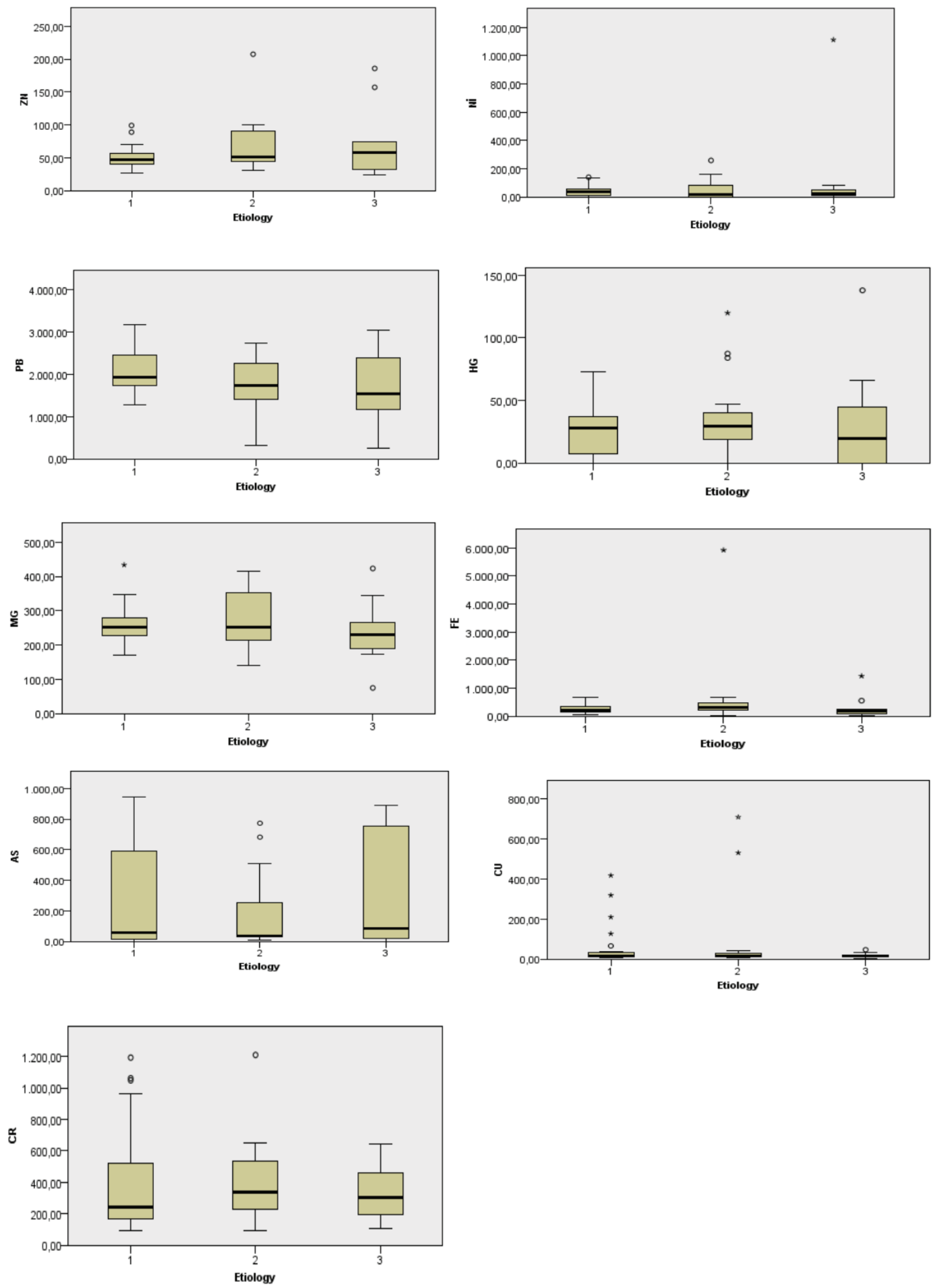

Figure 2. In this scheme, livers were grouped for nine heavy metals, according to etiology [HBV (group-1) vs. cryptogenic (group-2) vs. others (group-3)] 


\begin{tabular}{|c|c|c|c|c|c|c|c|c|c|c|c|c|}
\hline Patient & Sex & Etiology & Histopathology & HG & AS & ZN & CR & PB & CU & $\mathrm{Ni}$ & MG & $\mathrm{FE}$ \\
\hline 1 & M & Biliary Atresia & Cirrhosis & 9226,00 & 6722,00 & 32,49 & 191,70 & 1171,00 & 21,67 & 24,96 & 189,40 & 31,36 \\
\hline 2 & M & Colangio Cell & Colangioca & 65,63 & 891,90 & 74,76 & 460,20 & 2778,00 & 15,01 & 47,82 & 264,40 & 173,40 \\
\hline 3 & M & Cryptogenic & Cirrhosis & 42,56 & 751,90 & 157,00 & 382,60 & 2134,00 & 3,83 & 6182,00 & 227,50 & 48,52 \\
\hline 4 & M & Cryptogenic & Cirrhosis & 119,80 & 11,71 & 30,80 & 262,30 & 1479,00 & 7,89 & 0,00 & 220,10 & 60,44 \\
\hline 5 & M & Cryptogenic & Cirrhosis & 30,60 & 388,90 & 39,90 & 92,57 & 1351,00 & 8,12 & 134,40 & 198,20 & 301,10 \\
\hline 6 & $\mathrm{~F}$ & Cryptogenic & Fulminant & 47,15 & 510,50 & 51,15 & 413,70 & 1736,00 & 11,93 & 22,92 & 335,20 & 240,50 \\
\hline 7 & $\mathrm{~F}$ & Cryptogenic & Fulminant & 17,06 & 8983,00 & 94,39 & 648,60 & 308,50 & 12,53 & 0,00 & 391,60 & 175,10 \\
\hline 8 & $\mathrm{~F}$ & Cryptogenic & Fulminant & 0,00 & 36,08 & 47,18 & 529,00 & 1490,00 & 16,73 & 158,60 & 415,00 & 238,00 \\
\hline 9 & M & Cryptogenic & Fulminant & 83,87 & 50,10 & 32,65 & 539,20 & 561,50 & 16,86 & 29,91 & 144,90 & 285,50 \\
\hline 10 & M & Cryptogenic & Cirrhosis & 22,38 & 119,20 & 42,10 & 1210,00 & 2443,00 & 16,92 & 0,00 & 237,70 & 404,00 \\
\hline 11 & M & Cryptogenic & Cirrhosis & 33,03 & 77,12 & 88,25 & 254,80 & 2170,00 & 17,58 & 258,10 & 258,20 & 5925,00 \\
\hline 12 & $\mathrm{~F}$ & Cryptogenic & Cirrhosis & 7126,00 & 32,38 & 56,70 & 206,00 & 2021,00 & 19,70 & 17,99 & 260,50 & 34,36 \\
\hline 13 & $\mathrm{~F}$ & Cryptogenic & Cirrhosis & 20,76 & 773,10 & 56,51 & 100,30 & 2726,00 & 20,50 & 20,48 & 210,30 & 348,50 \\
\hline 14 & M & Cryptogenic & Cirrhosis & 24,74 & 28,26 & 51,11 & 358,60 & 1648,00 & 21,86 & 0,00 & 217,40 & 30,77 \\
\hline 15 & $\mathrm{~F}$ & Cryptogenic & Cirrhosis & 31,84 & 24,75 & 51,52 & 334,10 & 707,90 & 36,06 & 155,30 & 139,70 & 504,40 \\
\hline 16 & M & Cryptogenic & Cirrhosis & 87,30 & 682,10 & 93,84 & 255,50 & 2602,00 & 43,59 & 0,00 & 368,70 & 639,50 \\
\hline 17 & $\mathrm{~F}$ & HBV & Cirrhosis & 0,00 & 275,20 & 35,12 & 502,50 & 1838,00 & 5,26 & 0,00 & 218,00 & 70,04 \\
\hline 18 & M & HBV & $\mathrm{HCC}$ & 71,13 & 802,40 & 26,22 & 93,77 & 1283,00 & 5,31 & 0,00 & 169,90 & 74,51 \\
\hline 19 & M & HBV & Cirrhosis & 38,41 & 124,70 & 28,79 & 302,70 & 1778,00 & 5,44 & 16,04 & 207,80 & 256,60 \\
\hline 20 & M & HBV & Cirrhosis & 30,31 & 553,70 & 37,60 & 354,20 & 1273,00 & 6,43 & 20,23 & 260,70 & 171,10 \\
\hline 21 & M & HBV & Cirrhosis & 27,77 & 48,18 & 44,69 & 309,10 & 1389,00 & 9,13 & 34,41 & 278,60 & 39,71 \\
\hline 22 & M & HBV & Cirrhosis & 14,36 & 58,59 & 39,34 & 96,26 & 2131,00 & 11,27 & 116,40 & 211,60 & 177,10 \\
\hline 23 & M & HBV & Cirrhosis & 22,40 & 67,34 & 51,25 & 276,90 & 1848,00 & 11,56 & 0,00 & 230,10 & 163,30 \\
\hline 24 & M & HBV & Cirrhosis & 33,76 & 945,70 & 44,13 & 1193,00 & 1937,00 & 14,02 & 51,13 & 276,60 & 34,89 \\
\hline 25 & $\mathrm{~F}$ & HBV & Cirrhosis & 9328,00 & 796,90 & 61,57 & 208,30 & 2227,00 & 15,69 & 34,37 & 309,80 & 298,70 \\
\hline 26 & M & HBV & Cirrhosis & 0 & 10,89 & 48,5 & 207,7 & 1672 & 16 & 0 & 230,8 & 457,9 \\
\hline 27 & M & HBV & Cirrhosis & 137,90 & 0,00 & 54,19 & 152,30 & 1402,00 & 17,94 & 20,08 & 192,00 & 105,20 \\
\hline 28 & M & HBV & Cirrhosis & 28,51 & 44,27 & 52,48 & 126,20 & 2365,00 & 18,63 & 139,20 & 252,30 & 107,70 \\
\hline 29 & M & HBV & Cirrhosis & 0,00 & 17,07 & 49,08 & 187,20 & 2608,00 & 20,07 & 90,28 & 238,20 & 345,00 \\
\hline 30 & M & HBV & $\mathrm{HCC}$ & 67,04 & 631,90 & 70,05 & 534,00 & 2540,00 & 20,78 & 4196,00 & 278,10 & 365,60 \\
\hline 31 & M & HBV & $\mathrm{HCC}$ & 33,21 & 11,48 & 99,05 & 243,10 & 2775,00 & 24,87 & 10,31 & 345,80 & 639,80 \\
\hline 32 & M & HBV & Cirrhosis & 44,43 & 81,87 & 43,56 & 239,60 & 243,30 & 33,11 & 39,29 & 173,60 & 552,30 \\
\hline 33 & $\mathrm{~F}$ & HBV & Cirrhosis & 42,96 & 17,68 & 39,97 & 213,90 & 2516,00 & 36,60 & 131,40 & 256,60 & 323,20 \\
\hline 34 & M & HBV & Cirrhosis & 7,96 & 648,80 & 47,21 & 138,90 & 2052,00 & 65,64 & 35,63 & 247,00 & 213,60 \\
\hline 35 & M & HBV & Cirrhosis & 7347,00 & 0,00 & 47,00 & 144,60 & 1628,00 & 126,40 & 65,51 & 226,60 & 523,40 \\
\hline 36 & $\mathrm{~F}$ & HBV & Cirrhosis & 4509,00 & 756,90 & 48,90 & 1062,00 & 1777,00 & 209,20 & 36,13 & 247,10 & 164,90 \\
\hline 37 & $\mathrm{~F}$ & $\mathrm{HBV}+\mathrm{HCV}$ & Cirrhosis & 0,00 & 55,47 & 43,85 & 166,50 & 1929,00 & 13,57 & 0,01 & 270,10 & 181,40 \\
\hline 38 & M & $\mathrm{HBV}+\mathrm{HCV}+\mathrm{HDV}$ & Cirrhosis & 15,57 & 3117,00 & 40,68 & 168,20 & 2053,00 & 11,60 & 87,92 & 204,30 & 481,90 \\
\hline 39 & M & $\mathrm{HBV}+\mathrm{HDV}$ & $\mathrm{HCC}$ & 72,94 & 3658,00 & 66,87 & 1048,00 & 2771,00 & 16,16 & 18,06 & 315,20 & 118,30 \\
\hline 40 & M & $\mathrm{HCV}$ & Cirrhosis & 30,21 & 118,90 & 67,34 & 360,00 & 3043,00 & 46,65 & 1113,00 & 247,30 & 77,39 \\
\hline 41 & $\mathrm{~F}$ & Metastatic Tm & Adenoca & 0,00 & 85,38 & 23,67 & 541,90 & 271,60 & 3,23 & 0,00 & 74,66 & 162,60 \\
\hline 42 & $\mathrm{~F}$ & Otoimmune & Cirrhosis & 0,00 & 763,60 & 61,43 & 230,80 & 2388,00 & 14,82 & 22,16 & 423,50 & 238,70 \\
\hline 43 & $\mathrm{~F}$ & POLYCYSTIC & Cirrhosis & 0,41 & 70,77 & 185,90 & 640,00 & 1265,00 & 10,63 & 84,73 & 345,20 & 221,00 \\
\hline 44 & M & Tyrozinemia & Cirrhosis & 0,00 & 21,36 & 28,63 & 102,60 & 1666,00 & 17,60 & 9918,00 & 231,20 & 1432,00 \\
\hline 45 & M & Wilson & Cirrhosis & 35,85 & 58,81 & 60,60 & 911,90 & 1516,00 & 318,10 & 11,69 & 278,00 & 199,40 \\
\hline 46 & M & Wilson & $\mathrm{HCC}$ & 60,53 & 7691,00 & 88,85 & 964,90 & 3170,00 & 416,70 & 52,64 & 433,70 & 674,80 \\
\hline 47 & M & Wilson & Cirrhosis & 29,50 & 27,80 & 99,95 & 576,00 & 2358,00 & 529,70 & 0,00 & 252,80 & 424,10 \\
\hline 48 & $\mathrm{~F}$ & Wilson & Cirrhosis & 3392,00 & 32,68 & 207,50 & 196,10 & 1902,00 & 707,80 & 7,01 & 397,50 & 659,40 \\
\hline
\end{tabular}


progression of non-alcoholic fatty liver disease to steatohepatitis. On the other hand, iron is an essential micronutrient for organisms. Following the accumulation of excess iron in vital organs, dysfunctions can occur via the generation of reactive oxygen species. Hepatic iron overload is often seen in ESLD patients and iron accumulation in the liver is positively correlated with histological severity. Thus, iron overload can promote or suppress chronic liver diseases, depending on the concentration in the tissue microenvironment ${ }^{(34)}$. This fact is also valid for most of the heavy metals, except arsenic, lead, and mercury.

Lead is a naturally occurring metal found in the Earth's crust but toxic to the human body. Its widespread contamination has resulted in intensive human exposure, thereby posing significant public health problems worldwide ${ }^{(35)}$. Leadcontaminated ground or underground water, as well as food or beverage containers made of lead-polished ceramics and food containers made of lead alloys, can lead to the bioaccumulation of lead ${ }^{(36)}$. There seems to be a significant probability level of lead exposure in children playing with oreatings oil (37). The duration and dose of the exposure, as well as genetic differences, socio-economic status, and various environmental factors, may affect the magnitude of the exposure ${ }^{(38)}$.

Metallic or elemental mercury is another major source of toxicity in humans. Mercury is widely used in dental fillings, thermometers, compounds for skincare, medicinal products, fungicides, dyes, and soil fertilizers ${ }^{(39)}$. Notably, the mercury used in agriculture is suspended as mercury vapor in the air and is highly lipophilic, such that it can be effectively absorbed from the lung or oral mucosa ${ }^{(39)}$. Direct application of soil fertilizers and solid wastes, such as fungicides, leather tanning products, waste water treatment plant garbage, paper mills, batteries, and thermometers are the primary sources in the surrounding through which it accumulates in animal tissues ${ }^{(40)}$. The general population is exposed to mercury with amalgam primarily through diet (mercury accumulated seafood) and tooth filling (41). Depending on the chemical form and exposure pattern, mercury and its derivative compounds have a broad spectrum of toxicity ${ }^{(42)}$.

Arsenic is another primary toxicant, since its compounds are used in the manufacture of various products used in agricultural pesticides or environmental pest control, such as rat poison, wood preservation, paints production, wallpapers production, ceramics producion, and many manufacturing processes. As a result, in recent years, an increase in the contamination of drinking water due to arsenic and the subsequent exposure of humans to arsenic is observed ${ }^{(43,44)}$.

Manganese and copper are essential elements that are beneficial at low concentrations ${ }^{(45)}$. The metabolism of these metals is tightly regulated, since at high concentrations, depending on the route of exposure, these metals may adversely affect the structure and function of the liver, gastrointestinal tract, kidneys, brain, heart, blood, skin, and eyes ${ }^{\left({ }^{46}\right)}$. Wilson's disease is a hereditary copper metabolism disease that is inherited in an autosomal recessive manner. In Wilson's disease, crippled copper metabolism leads to the accumulation of copper in various tissues and organs, including the liver and brain. Medical treatment with zinc was introduced in 1961 by Schouwink. The objective of the treatment was to reduce the amount of accumulated copper by inducing a negative copper balance ${ }^{(47,48)}$. In this study, Wilson's disease was observed in four cases (Table 1, 3).

Exposure to $\mathrm{Cu}, \mathrm{Mn}$, and $\mathrm{Hg}$ alone and in combinations caused hydropic swelling of the hepatocytes, dilation of the sinusoids, and formation of binucleated hepatocytes with an increased inflammatory cell accumulation at the portal triad (21). Increased collagen deposition with associated fibrosis was also observed. Evalatuon of the ultrastructure of the hepatocyte revealed mitochondrial membrane damage arising from the swelling of the inner mitochondrial membrane, especially in hepatocytes exposed to $\mathrm{Mn}, \mathrm{Cu}$, $\mathrm{Mn}$, and $\mathrm{Hg}$ alone and as part of a mixture. This damage has been implicated in cellular damage, inflammation, and fibrosis, thereby increasing the risk of the associated diseases ${ }^{(21)}$. Depending on the chemical form and exposure pattern, mercury and its compounds have a broadspectrum of toxicity ${ }^{(49)}$.

Zinc is found in almost every cell of the human body (50). Zinc deficiency can impact several functions of the Liver, particularly the liver's capacity for regeneration. Zinc deficiency can result in cell and tissue damage by modulating specific signal cascades that result in damage to enzymes, mitochondria, and ribosomal structures ${ }^{(51-53)}$. Zinc levels in the serum of patients with hepatitis $C$ are lower as the severity of the disease advances. Accumulation of Copper in fibrotic livers, which is caused by chronic hepatitis $C$ viral infection, may contribut to hepatic injury and its presence increases the chances of hepatitis $\mathrm{C}$ viral infection. Cadmium and other metals, such as $\mathrm{Cu}, \mathrm{Co}, \mathrm{Pd}, \mathrm{Ni}, \mathrm{Fe}$, and $\mathrm{Mn}$, have toxic and immunomodulatory effects, which is similar to zinc, manganese, selenium, and copper in a variety of viral infections ${ }^{(51)}$. Multiple physiologic progressions in the liver are influenced by numerous vital trace metals, such as $\mathrm{Cu}$, 
$\mathrm{Fe}$, and Zn. These progressions consist of enzymatic activities, immune responses, oxidative-antioxidant status, erection, and protein function ${ }^{(54)}$.

The administration of zinc-based medicine showed that zinc causes the removal of stored excess copper and protected the liver, at least in part, by inducing the expression of intestinal and hepatic metallothionein ${ }^{(52,53)}$. Zinc is an essential trace element that exerts essential antioxidant, anti-inflammatory, and apoptotic effects. It is an essential micronutrient that plays fundamental roles in cellular metabolism, acting mostly by binding a wide range of proteins and affecting a broad spectrum of biological processes ${ }^{(53)}$.

Although not statistically significant in our study, the values of some heavy metal values in form of sporadic cases were observed to be quite high in some cases. For patients, it is essential for public and preventive health services to evaluate the patient and his/her environment in a very particular way. Besides, a matter to be considered, especially in liver transplants and cadaveric transplants donors, has to do with questioning whether the donor has a history of massive metal exposure and this pre-transplant questioning seems to be a particular issue in the checklist. This inquiry may prevent unexplained complications that may occur in donors and recipients, especially in liver transplant donors. For this purpose, it may be necessary to develop cheap, easy, and fast test methods for determining heavy metal levels.

\section{Study Limitations}

There are several limitations to this study. First, the study was a single-center observational study with a small number of patients with ESLD. The heavy metals analysis has different advantages and disadvantages as well as specificity and sensitivity. A rigorous preparation process is required for the samples and measurements are provided in the laboratory environment. Measurements are done using specialized equipment and devices, the process takes a long time, and the cost can be high. Therefore, we limited the number of samples and heavy metals we determined. The number of patients could be increased if the heavy metal levels are determined with an inexpensive and easy method for any patient undergoing hepatectomy for ESLD. Second, the serum concentrations of heavy metals can vary, depending on patient daily life activities, jobs, dietary habits, geographic regions (such as mining and industrial area). Another limitation was the lack of data records and standardization of patients. Each patient had to be evaluated separately according to city and region. In this regard, the insufficiencies in the records could be addressed through collaboration with public health physicians on the field.

\section{Conclusion}

In conclusion, this study provides valuable information for the prevention of ESLD, which poses a substantial economic burden worldwide. It will be beneficial to keep heavy metals in mind in the etiological examination of ESLD cases. Future modalities might be promising if heavy metals in the liver are easily analyzed using improved technology. Today, for these reasons, governments, in order to protect the public health, should make the necessary policies that would ensure the establishment of waste cleaning and emission facilities for industrial organizations and all industrial organizations should be strictly supervised in this regard.

\section{Main Points}

1. ESLD is a devastating health problem. Accumulations of heavy metals have long been claimed to direct hepatic toxicity and have been implicated in chronic liver diseases.

2. We investigated the bioaccumulation of heavy metals in explanted liver tissue of patients with ESLD using AAS to find a correlation between the heavy metal accumulation in the failed livers explanted from the patients with ESLD and the disease's etiology (especially the unknown/cryptogenic).

3. The bioaccumulation of nine heavy metals $(\mathrm{Hg}, \mathrm{As}, \mathrm{Zn}, \mathrm{Cr}$, $\mathrm{Pb}, \mathrm{Cu}, \mathrm{Ni}, \mathrm{Mg}$, and $\mathrm{Fe}$ ) was evaluated.

4. Accumulated total heavy metal levels in explanted livers of patients with ESLD do not appear to be a differential diagnosis tool, except the copper levels for Wilson's disease.

\section{Ethics}

Ethics Committee Approval: The study was approved by the local ethics committee (project no: TIPFBAP/2014-0007).

Informed Consent: The information of the patients was retrospectively analyzed.

Peer-review: Externally peer reviewed.

\section{Authorship Contributions}

Concept: S.H., A.D., M.A., M.Ö.Ç., Ö.Y., M.A.I., S.Y., Design: S.H., A.D., M.A., M.Ö.Ç., Ö.Y., M.A.I., S.Y., Data Collection or Processing: S.H., A.D., M.A., M.Ö.Ç., Ö.Y., M.A.I., S.Y., Analysis or Interpretation: S.H., A.D., M.A., M.Ö.Ç., Ö.Y., M.A.I., S.Y., Literature Search: S.H., A.D., M.A., M.Ö.Ç., Ö.Y., M.A.I., S.Y., Writing: S.H., A.D., M.A., M.Ö.Ç., Ö.Y., M.A.I., S.Y.

Conflict of Interest: No conflicts of interest were declared by the authors. 
Financial Disclosure: There was funding support for carrying out this study as an individual research project from Adıyaman University (project no: TIPFBAP/2014-0007).

\section{REFERENCES}

1. Halliwell B, Gutteridge JM. Role of free radicals and catalytic metal ions in human disease: an overview. Methods Enzymol. 1990;186:1-85. doi: 10.1016/0076-6879(90)86093-b.

2. Pramoolsinsap C, Promvanit N, Komindr S, Lerdverasirikul P, Srianujata S. Serum trace metals in chronic viral hepatitis and hepatocellular carcinoma in Thailand. J Gastroenterol. 1994;29:610-5. doi: 10.1007/BF02365444.

3. Aslam N, Iqbal MS, Hussain SM, et al. Effects of chelating agents on heavy metals in Hepatitis C Virus (HCV) patients. Math Biosci Eng. 2019;16:1138-49. doi: 10.3934/mbe.2019054.

4. Kahvecioglu Ö, Kartal G, Güven A, Timur S. Metallerin çevresel etkileri-I. Metalurji Dergisi 2004;136:47-53.

5. Wirth JJ, Mijal RS. Adverse effects of low level heavy metal exposure on male reproductive function. Syst Biol Reprod Med. 2010;56:147-67. doi: 10.3109/19396360903582216.

6. Meeker JD, Rossano MG, Protas B, et al. Cadmium, lead, and other metals in relation to semen quality: human evidence for molybdenum as a male reproductive toxicant. Environ Health Perspect. 2008;116:1473-9. doi: 10.1289/ehp.11490.

7. Lavi N, Alfassi ZB. Determination of trace amounts of cadmium, cobalt, chromium, iron, molybdenum, nickel, selenium, titanium, vanadium and zinc in blood and milk by neutron activation analysis. Analyst. 1990;115:817-22. doi: 10.1039/an9901500817.

8. Landrigan PJ. Occupational and community exposures to toxic metals: lead, cadmium, mercury and arsenic. West J Med. 1982;137:531-9.

9. Ferrís Tortajada J, Ortega García JA, Garcia I Castell J, López Andreu JA, Ribes Koninckx C, Berbel Tornero O. Factores de riesgo para los tumores hepáticos malignos pediátricos [Risks factors for pediatric malignant liver tumors]. An Pediatr (Barc). 2008;68:377-84. (Spanish) doi: 10.1157/13117711.

10. Axelson O, Dahlgren E, Jansson CD, Rehnlund SO. Arsenic exposure and mortality: a case-referent study from a Swedish copper smelter. Br J Ind Med. 1978;35:8-15. doi: 10.1136/oem.35.1.8.

11. Straub AC, Clark KA, Ross MA, et al. Arsenic-stimulated liver sinusoidal capillarization in mice requires NADPH oxidase-generated superoxide. J Clin Invest. 2008;118:3980-9. doi: 10.1172/JCl35092.

12. Datta DV, Mitra SK, Chhuttani PN, Chakravarti RN. Chronic oral arsenic intoxication as a possible aetiological factor in idiopathic portal hypertension (non-cirrhotic portal fibrosis) in India. Gut. 1979;20:37884. doi: 10.1136/gut.20.5.378.

13. John H. Duffus "Heavy metals" a meaningless term? (IUPAC Technical Report) Pure Appl Chem. 2002;74:793-807. doi:10.1351/ pac200274050793

14. Inoue $N$, Ikawa $M$, Isotani A, Okabe $M$. The immunoglobulin superfamily protein Izumo is required for sperm to fuse with eggs. Nature. 2005;434:234-8. doi: 10.1038/nature03362.

15. Shahsavari A, Tabatabaei Yazdi F, Moosavi Z, Heidari A, Sardari P. A study on the concentration of heavy metals and histopathological changes in Persian jirds (Mammals; Rodentia), affected by mining activities in an iron ore mine in Iran. Environ Sci Pollut Res Int. 2019;26:12590-12604. doi: 10.1007/s1l356-019-04646-9.

16. Fashola MO, Ngole-Jeme VM, Babalola 00. Heavy Metal Pollution from Gold Mines: Environmental Effects and Bacterial Strategies for Resistance. Int J Environ Res Public Health. 2016;13:1047. doi: 10.3390/ ijerph13111047.
17. Tchounwou PB, Yedjou CG, Patlolla AK, Sutton DJ. Heavy metal toxicity and the environment. Exp Suppl. 2012;101:133-64. doi: 10.1007/978-37643-8340-4_6.

18. Kumar A, Khushboo, Pandey R, Sharma B. Modulation of superoxide dismutase activity by mercury, lead, and arsenic. Biol Trace Elem Res. 2020;196:654-61. doi: 10.1007/sl2011-019-01957-3.

19. Afify M, Diaa M, Elmaksoud EA. Serum levels of trace elements in Egyptian patients with chronic hepatitis $C$ under interferon therapy. J Genet Eng Biotechnol. 2012;10:81-6.

20. Piekuse $L$, Kreile $M$, Zarina $A$, et al. Association between inherited monogenic liver disorders and chronic hepatitis C. World J Hepatol. 2014;6:92-7. doi: 10.4254/wjh.v6.i2.92.

21. Kazi TG, Kolachi NF, Afridi HI, et al. Effects of mineral supplementation on Liver cirrhotic/cancer male patients. Biol Trace Elem Res. 2012;150:8190. doi: 10.1007/s12011-012-9501-y.

22. Dhanraj P, Venter C, Bester MJ, Oberholzer HM. Induction of hepatic portal fibrosis, mitochondria damage, and extracellular vesicle formation in Sprague-Dawley rats exposed to copper, manganese, and mercury, alone and in combination. Ultrastruct Pathol. 2020;44:182-92. doi: 10.1080/01913123.2020.1731638.

23. Hedayati A. Liver as a target organ for eco-toxicological studies. J Coast Zone Manag. 2016;19:1-2. doi: 10.4172/2473-3350.1000ell8.

24. Liu T, He W, Yan $C$, et al. Roles of reactive oxygen species and mitochondria in the cadmium-induced injury of liver cells, Toxicol Ind Health. 2010;27:249-56. doi: 10.1177/0748233710386408.

25. Ates $M$, Hatipoglu $S$, Dirican A, et al. Right-lobe living-donor liver transplantation in adult patients with acute liver failure. Transplant Proc. 2013;45:1948-52. doi: 10.1016/j.transproceed.2012.10.056.

26. Malhi H, Guicciardi ME, Gores GJ. Hepatocyte death: a clear and present danger. Physiol Rev. 2010;90:1165-94. doi: 10.1152/physrev.00061.2009.

27. Hatipoglu S, Bulbuloglu B, Piskin T, Kayaalp C, Yilmaz S. Living donor liver transplantation for alveolar echinococcus is a difficult procedure. Transplant Proc. 2013;45:1028-30. doi: 10.1016/j. transproceed.2013.02.084.

28. Hatipoglu S, Bulbuloglu E, Ates M, Kayaalp C, Yilmaz S. Liver transplantation following blunt liver trauma. Transplant Proc. 2012;44:1720-1. doi: 10.1016/j.transproceed.2012.04.009.

29. Hatipoglu S, Olmez A, Ozgor D, Kayaalp C, Yilmaz S. Living donor liver transplantation in the absence of inferior vena cava: a case report. Transplant Proc. 2012;44:1761-3. doi: 10.1016/j. transproceed.2012.05.053.

30. Tardu A, Karagul S, Yagci MA, et al. Histopathological examination of explanted liver after transplantation in patients with cryptogenic cirrhosis. Transplant Proc. 2015;47:1450-2. doi: 10.1016/j. transproceed.2015.04.020.

31. Marmur J, Bergquist A, Stål P. Liver transplantation of patients with cryptogenic cirrhosis: clinical characteristics and outcome. Scand J Gastroenterol. 2010;45:60-9. doi: 10.3109/00365520903384742.

32. Charlton MR, Kondo M, Roberts SK, Steers JL, Krom RA, Wiesner RH. Liver transplantation for cryptogenic cirrhosis. Liver Transpl Surg. 1997L:;:359-64. doi: 10.1002/lt.500030402.

33. Ayata G, Gordon FD, Lewis WD, et al. Cryptogenic cirrhosis: clinicopathologic findings at and after liver transplantation. Hum Pathol. 2002;33:1098-104. doi: 10.1053/hupa.2002.129419.

34. Atarashi M, Izawa $T$, Kuwamura M, Yamate J. [The role of iron overload in the progression of nonalcoholic steatohepatitis (NASH)]. Nihon Yakurigaku Zasshi. 2019;154:61-5. (Japanese) doi: 10.1254/ fpj.154.61.

35. Huali $T$, Honglei $P$, Feng $W$, et al. Effects of combined administration of calcium, iron, zinc, chrysanthemum flavonoids, and DMSA on 
the treatment of lead intoxication in mice. J Biochem Mol Toxicol. 2020;34:e22425. doi: 10.1002/jbt.22425.

36. Telisman S, Cvitkovic P, Jurasovic J, Pizent A, Gavella M, Rocic B. Semen quality and reproductive endocrine function in relation to biomarkers of lead, cadmium, zinc, and copper in men. Environ Health Perspect. 2000;108:45-53. doi: 10.1289/ehp.0010845.

37. Teijón C, Olmo R, Blanco D, Romero A, Teijón JM. Low doses of lead: effects on reproduction and development in rats. Biol Trace Elem Res. 2006;111:151-65. doi: 10.1385/BTER:111:1:151.

38. Apostoli P, Bellini A, Porru S, Bisanti L. The effect of lead on male fertility: a time to pregnancy (TTP) study. Am J Ind Med. 2000;38:310-5. doi: 10.1002/1097-0274(200009)38:3<310::aid-ajim10>3.0.c0;2-9.

39. Crinnion WJ. Environmental medicine, part three: long-term effects of chronic low-dose mercury exposure. Altern Med Rev. 2000;5:209-23.

40. Arabi M, Sanyal SN, Kanwar U, Anand RJK. The Effect of Antioxidants on Nicotine and Caffeine Induced Changes in Human Sperm-an in vitro Study. In: De Vriese SR, Christopher AB, editors. Male fertility and lipid metabolism. Champaign, IL, USA: AOCS Press; p. 250-67.

41. Arabi M, Heydarnejad MS. In vitro mercury exposure on spermatozoa from normospermic individuals. Pak J Biol Sci 2007; 10: 2448-53. doi: 10.3923/pjbs.2007.2448.2453.

42. Satoh H. Behavioral teratology of mercury and its compounds. Tohoku J Exp Med. 2003;201:1-9. doi: 10.1620/tjem.201.1.

43. Pant N, Kumar R, Murthy RC, Srivastava SP. Male reproductive effect of arsenic in mice. Biometals. 2001;14:113-7. doi: 10.1023/a:1016686113763.

44. Winski SL, Carter DE. Arsenate toxicity in human erythrocytes: characterization of morphologic changes and determination of the mechanism of damage. J Toxicol Environ Health A. 1998;53:345-55. doi: 10.1080/009841098159213.
45. Bost M, Houdart S, Oberli M, Kalonji E, Huneau JF, Margaritis I. Dietary copper and human health: current evidence and unresolved issues. J Trace Elem Med Biol. 2016;35:107-15. doi: 10.1016/j.jtemb.2016.02.006.

46. Park JD, Zheng W. Human exposure and health effects of inorganic and elemental mercury. J Prev Med Public Health. 2012;45:344-52. doi: 10.3961/jpmph.2012.45.6.344.

47. Hoogenraad TU. Paradigm shift in treatment of Wilson's disease: zinc therapy now treatment of choice. Brain Dev. 2006;28:141-6. doi: 10.1016/j.braindev.2005.08.008.

48. Huster D. Wilson disease. Best Pract Res Clin Gastroenterol. 2010;24:5319. doi: 10.1016/j.bpg.2010.07.014.

49. Satoh H. Behavioral teratology of mercury and its compounds. Tohoku J Exp Med. 2003;201:1-9. doi: 10.1620/tjem.201.1.

50. Science BM, Medical K. Selenium, iron, copper, and zinc levels and copper-to-zinc ratios in the serum of patients at different stages of viral hepatic diseases. Biol Trace Elem Res. 2006;109:15-23. doi: 10.1385/ BTER:109:1:015.

51. Gall JE, Boyd RS, Rajakaruna N. Transfer of heavy metals through terrestrial food webs: a review. Environ Monit Assess. 2015;187:201. doi: 10.1007/s10661-015-4436-3.

52. Nishikawa $H$, Enomoto $H$, Yoh $K$, et al. Serum zinc concentration and quality of life in chronic liver diseases. Medicine (Baltimore). 2020;99:el8632. doi: 10.1097/MD.0000000000018632.

53. Grüngreiff $K$, Reinhold $D$, Wedemeyer $H$. The role of zinc in liver cirrhosis. Ann Hepatol. 2016;15:7-16. doi: 10.5604/16652681.1184191.

54. Ibs KH, Rink L. Zinc-altered immune function. J Nutr. 2003;133(5 Suppl 1):1452S-6S. doi: 10.1093/jn/133.5.1452S. 